\title{
Fertility and Sperm Quality of 1- and 2-year-Old Native Ganders Used for Natural Mating and Artificial Insemination
}

\author{
Mehmet Akif BOZ ( $\sim$ bozmakif@gmail.com ) \\ Yozgat Bozok University https://orcid.org/0000-0002-7452-6895 \\ Hatice BAŞ \\ Bozok University: Bozok Universitesi \\ Musa SARICA \\ Ondokuz Mayis University: Ondokuz Mayis Universitesi \\ Kadir ERENSOY \\ Ondokuz Mayis University: Ondokuz Mayis Universitesi
}

\section{Research Article}

Keywords: Turkish geese, gander age, natural mating, artificial insemination, fertility, sperm quality

Posted Date: February 26th, 2021

DOI: https://doi.org/10.21203/rs.3.rs-246983/v1

License: (c) (i) This work is licensed under a Creative Commons Attribution 4.0 International License. Read Full License 


\section{Abstract}

In the present study, the fertility rate and egg-hatching results from either natural mating or artificial insemination using 1-and 2-year-old domestic Turkish geese were compared. Sperm quality traits of 1-and 2-year-old ganders used for mating were determined. The study comprised 72 two-year-old females, 12 one-year-old, and 12 two-year-old ganders at the beginning of the laying period. Thirty-six female geese were mated naturally (18 with 1-year-old ganders, 18 with 2-year-old ganders); the remaining 36 were artificially inseminated (18 with 1-year-old ganders, 18 with 2-year-old ganders). Twenty-four ganders were separated into groups (12 for natural mating; 12 for artificial insemination). The male-to-female ratio in both mating protocols was 1:3. The geese were housed during the laying period in a natural and artificially ventilated house under natural lighting (increased day length). Quality traits, such as semen volume, sperm concentration, sperm quality factor (SQF), sperm motility, and some sperm morphological properties were determined. Fertility was higher in the groups containing 2-year-old ganders than in those using 1-year-old ganders $(P<0.05)$. The effect of insemination on semen volume, sperm concentration, SQF, sperm motility, total live sperm, normal sperm, macrocephalus sperm, and dead sperm was determined to be significant $(P<$ 0.05). As a result, there is a need to improve the egg production and broody behavior traits of domestic Turkish geese. In addition, the use of 2-year-old geese in artificial insemination is appropriate and will contribute positively to the breeding and selection process.

\section{Introduction}

Geese, are a species that can digest high cellulose-containing feedstuffs and herbs; are resistant to adverse climatic conditions, especially cold environments and disease factors; have low housing requirements; and produce highly nutritional food (Labatut, 2002). Despite these desirable properties, they have a shorter laying period, lower fertility rates, and lower egg yield than other poultry. In addition, sperm concentration, ejaculate volume, and live sperm count per unit ejaculate are lower in geese than in other poultry (Lukaszewicz et al. 2000), which results in a decrease in reproduction with low egg yields due to low fertility rates. Furthermore, the production of qualified breeding parents is difficult because of low fertility rates, and the insufficient knowledge and experience of breeders increase the problem. Hatching difficulties also significantly limit gosling production (Liu et al. 2008). In the geese and other poultry species that enter a laying season, artificial insemination can be used effectively to increase fertility rates during periods of low sexual activity (Kulaksı, 2016). For artificial insemination in geese using fresh semen to become widespread and practical, the fertility rate results must be compared to those of naturally mating geese. It has been generally observed that fertility rates from natural mating are lower than those from artificial insemination (Kowalczyk and Lukaszewicz, 2012); therefore, artificial insemination can increase the yield of fertile eggs from domestic geese that previously had low egg yields and fertility rates. Because the sperm quality in artificial insemination is also determined, low fertility rates resulting from this can be controlled. There have been studies on sperm quality and reproduction using natural mating and artificial insemination of different goose breeds (Liu et al. 2008; Lukaszewicz, 2010]; however, none were conducted using the local geese native to Turkey. Turkish geese are the most common breed in Turkey. As a result of increasing the yield of offspring by artificial insemination, the number of goslings will increase, and the profitability will be increased at the same time.

Turkish domestic geese attain sexual maturity at a late age (8-9 months). For this reason, it has become necessary to use males and females for breeding for 2-3 years. In Turkey, geese producers can use stock up to 5-6 years old for production (Boz et al. 2014; Demir et al. 2013). Studies have indicated that the annual egg yield of this population was 11-13 eggs, for which the body weight, egg yield, and breeding traits are to be improved, the average laying period was 60-75 d, and the laying season was February-May. Studies have also reported that the fertility rate in this population was between $70 \%$ and $80 \%$ (Boz et al. 2014; Demir et al. 2013). Several studies have indicated that the domestic genotypes are inadequate in terms of egg yield, fertility, and incubation results (Arslan and Saatçi, 2003; Boz et al. 2014; Demir et al. 2013;Tilki and İnal, 2004). In particular, the efficiency of mating young males to old females or old males to young females compared to that of mating geese of the same age has not been sufficiently demonstrated. It will also be easier to obtain these mating pairs using artificial insemination than natural mating. In this study, the differences in the fertility rate and hatching results of eggs obtained by natural mating and artificial insemination of 2-year-old female Turkish domestic geese were investigated. The quality of the sperm from 1-and 2year-old ganders used in both mating protocols was determined over different periods. 


\section{Materials And Methods}

\section{Animals}

The animal used in the study were 72 two-year-old female domestic geese and 24 male geese, 12 one-year-olds and 12 twoyear-olds. Thirty-six female geese were naturally mated (18 females with 1-year-old males; 18 females with 2-year-old males). The other 36 female geese were artificially inseminated (18 females were inseminated with the sperm of 1-year-olds; 18 females with the sperm of 2-year-olds). In both the natural mating and artificial insemination groups, the male: female ratio was 1: 3 (1区: 3囚).

In the present study, all female geese had an average live weight per experiment of $4.00 \pm 0.03 \mathrm{~kg}$ (between 3.75 and $4.21 \mathrm{~kg}$ ). The live weights per experiment for the 1-year-old and 2-year-old ganders were $4.54 \pm 0.03 \mathrm{~kg}$ (between 4.27 and $4.79 \mathrm{~kg}$ ) and $4.60 \pm 0.3 \mathrm{~kg}$ (between 4.33 and $4.80 \mathrm{~kg}$ ), respectively. The experimental protocol was approved by the Ethical Committee on Animal Experimentation of the University of Niğde Ömer Halisdemir.

\section{Rearing and feeding}

Our study was conducted in Yozgat Province, Turkey (located between $34^{\circ} 05^{\prime}-36^{\circ} 10^{\prime} \mathrm{N}$ longitude and $38^{\circ} 40-40^{\circ} 18^{\prime} \mathrm{E}$ latitude), where terrestrial climatic conditions are dominant. The geese were housed in an $8 \mathrm{~m} \times 16 \mathrm{~m}$ enclosure with windows and both natural and artificial ventilation. The housing conditions changed with natural light and seasonal temperature. The daylight duration at the beginning of the study was $9.5 \mathrm{~h}$ and reached $13.8 \mathrm{~h}$ by the end of the study; temperatures ranged between -3.5 and $33.8^{\circ} \mathrm{C}$. The study was conducted between January and June 2019. In the natural mating group, 3 females and 1 male were placed in $4.5 \mathrm{~m}^{2}$ sections with 6 replicates for 1-year-old ganders (NM-1), and 6 replicates for 2-year-old ganders (NM-2). In the artificial insemination group, 6 replicates of 3 females were created, and the 18 female geese were artificially inseminated with the sperm of 1-year-old ganders (Al-1) and 18 females with the sperm of 2-year-old ganders (Al-2). Female geese used in artificial insemination were housed individually in pens of $4.5 \mathrm{~m}^{2}$, and the ganders were housed in $1 \mathrm{~m}^{2}$ pens.

During the study, the animals had free access to fresh drinking water and were fed $250 \mathrm{~g} / \mathrm{animal} / \mathrm{d}$. Egg starter feed (17.5\% crude protein, $7 \%$ crude cellulose, $13.0 \%$ crude ash, 2.0-2.2\% $\mathrm{Ca}, 11.51 \mathrm{MJ} / \mathrm{Kg}$ metabolic energy) was provided for 1 month before the laying period. Egg production feed (17.0\% crude protein, 7.0\% crude cellulose, 13.0\% crude ash, 3.5-4.0 Ca, 11.51 $\mathrm{MJ} / \mathrm{Kg}$ metabolic energy) was provided from the beginning of the egg yield until the end of the study.

\section{Egg yield and broodiness}

The eggs collected in all compartments from the beginning of the laying period were individually numbered according to the trial groups. The period during which egg production did not occur in all groups for 1 continuous week after the start of laying was taken as the laying period. In addition, the brooding geese were determined according to the treatment groups and recorded. Egg yield and broodiness were expressed as percentages (\%) for all experimental groups. In the experimental groups, the first laying took place on January 27, 2019, and the last laying took place on April 15, 2019, followed a $7 \mathrm{~d}$ period when no laying occurred. The period between these two dates was accepted as the laying period, calculated as $79 \mathrm{~d}$.

\section{Fertility and hatching results}

Eggs obtained from the experimental groups were kept in egg storage cabinets for $7 \mathrm{~d}$ at $15-16^{\circ} \mathrm{C}$ and $70 \%$ relative humidity and then placed in an incubator. Egg fertility was controlled at 8 days of incubation, and fertilized eggs were also analyzed for embryonic deaths and excluded from incubation. The fertility rates were determined according to the experimental groups. During the incubation period (8-27 d), the eggs were regularly cooled and moistened using water. The incubation conditions and the procedures performed during the incubation period are provided in Table 1 . At $28 \mathrm{~d}$, the eggs were taken from the incubator, placed into a hatchery machine, and separately coded according to the treatment group. Incubation traits (early, middle, late embryo deaths, pipped embryonic mortalities, contaminated eggs, morbid/dead eggs, hatchability, and incubation 
yield) were determined according to the treatment group for the eggs that did not hatch at the end of the incubation process. The eggs obtained were incubated every 7 days. During the study, 11 incubation procedures were carried out. A total of 762 eggs were used in experimental groups (NM-1: 200, NM-2: 164, Al-1: 157, and Al-2: 241 eggs) for these incubation procedures.

Table 1 Incubation conditions adopted for the study

\begin{tabular}{|lllll|}
\hline $\mathbf{2 1}$ & $\begin{array}{l}\text { Temperature } \\
\left.\mathbf{(}{ }^{\circ} \mathbf{C}\right)\end{array}$ & $\begin{array}{l}\text { Humidity } \\
\mathbf{( \% )}\end{array}$ & Rotating & Procedure \\
\hline $1-7$ & 37.7 & $55-60$ & Once/h & - \\
\hline 8 & 37.7 & $55-60$ & Once/h & Fertility control + cooling + water spraying \\
\hline 9 & 37.7 & $55-60$ & Once/h & 10 min. cooling + water spraying \\
\hline 10 & 37.7 & $55-60$ & Once/h & 15 min. cooling + water spraying \\
\hline 11 & 37.7 & $55-60$ & Once/h & 20 min. cooling + water spraying \\
\hline 12 & 37.7 & $55-60$ & Once/h & 25 min. cooling + water spraying \\
\hline 13 & 37.7 & $55-60$ & Once/h & 30 min. cooling + water spraying \\
\hline $21-24$ & 37.5 & $55-60$ & Once/h & 30 min. cooling + water spraying \\
\hline $25-27$ & 37.2 & $55-60$ & Once/h & 35 min. cooling + water spraying \\
\hline $28-31$ & 36.9 & $55-60$ & Once/h & 35 min. cooling + water spraying \\
\hline
\end{tabular}

\section{Semen collection and artificial insemination}

Semen collection was performed 3 times a week for artificial insemination ( 2 times a week towards the end of the reproductive period) for the continuity of sperm production. The insemination of the females was carried out twice a week, and the geese were inseminated 26 times in total. The semen collection was completed within 20-25 minutes in each cycle. Dorsa-abdominal massage was applied to ganders for collecting semen. Semen was diluted 1:1 with saline and kept at $4^{\circ} \mathrm{C}$, and injected into females within 45 minutes. During the study, depending on the artificial insemination treatment group, semen taken from the same males was injected into the same females (semen from 1 male was multiplied and injected into 3 females). For this purpose, male and female groups in the artificial insemination group were enumerated. Needle-free tubercle injectors (HSW HENKE-JECT ${ }^{\circledR}$ - TBC Dosage syringe for tuberculin testing $2 \mathrm{ml}$, Germany) were used for injecting semen. At each insemination (for each female goose), $0.15 \mathrm{ml}$ of diluted semen was injected 3-4 cm deep into the oviduct (Liu et al. 2008; Lukaszewicz, 2002; Łukaszewicz, 2010).

For semen quality traits, semen was collected from males in all experimental groups once every 2 weeks in the morning and evaluated for quality traits within 30 minutes (Grunder and Pawluczuk, 1991; Liu et al. 2008). Three replicate samples were obtained from each of three ganders. Although the laying period ended in April, the male geese (in the same experimental order) continued to produce sperm. Since semen could not be obtained despite milking, the determination of semen quality traits in males was terminated on May 15, 2019. Semen collection started on January 17, 2019, and ended on May 15, 2019. The semen collection period lasted 119 days.

\section{Determination of sperm quality}

The collected semen samples were examined for specific parameters, such as ejaculate volume, color, blood, fecal contamination, sperm motility, concentration, and sperm morphology. Both sperm viability and morphology were investigated using an Olympus E-330 light microscope after the specimens were stained with eosin-nigrosin and Giemsa. Eosin-nigrosin staining is conducted by spreading the preparations on a glass slide and adding an eosin-nigrosin suspension onto the semen 
sample. After drying, it is fixed and examined. Using this technique, the concentration between the sperm heads is increased by the nigrosin. In Giemsa staining, the semen sample is dropped onto a slide, and a peripheral smear is conducted. The dye is then placed on the slide and left to stand for some time. Later, the excess dye is removed, and the slide is examined. These two staining methods complement each other. Sperm count, concentration, and motility were determined using a MicroCell counting chamber. According to the results obtained, the sperm quality factor was determined using the following formula (Liu et al. 2008; Lukaszewicz, 2002):

Sperm quality factor $=$ sperm concentration $\left(n \times 10^{6} \mathrm{~mL}^{-1}\right) \times$ ejaculate volume $(\mathrm{mL}) \times$ live and normal-morphology sperm count (\%) / 100

\section{Statistical analyses}

The study was arranged according to a $2 \times 2$ factorial trial design, and the insemination method and gander age were considered as the main effects. All variables were examined for normality and homogeneity of variance using the Shapiro-Wilk and Levene tests, respectively. Results that were not normally distributed were log-transformed (especially sperm quality traits) before univariate analyses were conducted. Other "percentage" data were determined to have homogeneous distributions (Levene test; $p$ > 0.05). All data were subjected to univariate analyses using a model that contained the main effects of insemination type, age, and their interaction. Treatment means were separated using Duncan's multiple range test. All tests were performed at a 0.05 significance level. All data analyses were performed using the SPSS software program (Version 21.0, licensed by Ondokuz Mayis University).

\section{Results}

\section{Egg yield and broodiness}

The effect of insemination type and age on average daily egg yields and broodiness is given in Table 2, and the change in the laying period is given in Table 3. Depending on the type of insemination, there were no differences between the experimental groups in terms of egg yield. There was higher broodiness in experimental groups Al-1 and Al-2, (P凶0.05). Depending on the laying period, the highest egg yield was obtained in February; the lowest yields were produced in January and April ( $P \otimes 0.05)$. As the laying period progressed in all groups, broodiness also increased $(P \otimes 0.05)$.

Table 2 Average daily egg yield and broodiness by insemination type and age 


\begin{tabular}{|llll|}
\hline Insemination method & Ganders age & Daily egg yield (\%) & Broodiness (\%) \\
\hline Natural mating & 1-year-old & 12.8 & 28.4 \\
\cline { 2 - 4 } & 2-year-old & 12.7 & 25.8 \\
\cline { 2 - 4 } & Total & 12.8 & 27.1 \\
\hline Artificial insemination & 1-year-old & 11.9 & 33.3 \\
\cline { 2 - 4 } & 2-year-old & 16.4 & 32.6 \\
\hline Total & Total & 14.1 & 33.0 \\
\hline SEM & 1-year-old & 12.3 & 30.9 \\
\hline Effects & 2-year-old & 14.6 & 29.2 \\
\hline Insemination method & & 0.600 & 1.110 \\
\hline Ganders age & & & 0.008 \\
\hline Interaction & & 0.253 & 0.456 \\
\hline
\end{tabular}

Notes: SEM: Standard error of the mean

Table 3 Average daily egg yield and broodiness by laying period

\begin{tabular}{|lllllll|}
\hline Properties (\%) & \multicolumn{2}{c|}{ Laying period } & & & \\
\hline & Jan & Feb & Mar & Apr & SEM & P \\
\hline Daily egg yield & $6.9^{\mathrm{c}}$ & $19.4^{\mathrm{a}}$ & $13.9^{\mathrm{b}}$ & $3.5^{\mathrm{c}}$ & 0.609 & 0.000 \\
\hline Broodiness & $0.0^{\mathrm{c}}$ & $0.4^{\mathrm{c}}$ & $42.6^{\mathrm{b}}$ & $69.4^{\mathrm{a}}$ & 1.110 & 0.000 \\
\hline
\end{tabular}

Notes: SEM, standard error of the mean; ${ }^{a, b, c}$. The differences between the means shown in different letters in the same row are statistically significant

\section{Incubation traits}

The insemination method and the effects of gander age on hatching traits are given in Table 4. Egg fertility differed significantly according to insemination type and age $(p<0.05)$. In natural mating, the fertility rate of eggs was higher than in artificial insemination (81.9\% vs. $74.4 \%$ ) and higher in 2-year-old geese compared to 1-year-old geese (84.5\% vs. $71.8 \%)$. While the incubation yield was not affected by the insemination method, the age of the geese significantly affected the incubation yield. It was higher in groups mated or inseminated by 2-year-old ganders than those mated or inseminated by the 1-year-old ganders: $72.4 \%$ and $59.2 \%$, respectively $(p<0.01)$. Hatchability, early-middle-late and pipped embryonic mortalities, contaminated egg amounts, and morbid/dead chick ratios did not differ according to insemination method and gander age ( $p>$ 0.05 ; Table 4).

Table 4 Incubation results after natural mating and artificial insemination 


\begin{tabular}{|c|c|c|c|c|c|c|c|c|c|c|}
\hline Insemination method & Ganders age & $\mathrm{F}$ & $\mathrm{H}$ & IY & EEM & MEM & LEM & PEM & CE & MDC \\
\hline \multirow[t]{3}{*}{ Natural mating } & 1 old & 75.4 & 84.1 & 63.4 & 5.4 & 2.1 & $0.7 \mathrm{~b}$ & 3.7 & 3.1 & 0.8 \\
\hline & 2 old & 88.5 & 85.3 & 75.3 & 3.5 & 2.2 & $5.7 a$ & 0.9 & 2.4 & 0.0 \\
\hline & Total & 81.9 & 84.7 & 69.4 & 4.4 & 2.1 & 3.2 & 2.3 & 2.8 & 0.4 \\
\hline \multirow[t]{3}{*}{ Artificial insemination } & 1 old & 68.1 & 80.6 & 54.9 & 8.7 & 1.5 & $2.8 a b$ & 2.3 & 4.0 & 0.0 \\
\hline & 2 old & 80.6 & 86.1 & 69.5 & 6.2 & 1.7 & $1.6 \mathrm{~b}$ & 1.7 & 2.7 & 0.0 \\
\hline & Total & 74.4 & 83.3 & 62.2 & 7.5 & 1.6 & 2.2 & 2.0 & 3.3 & 0.0 \\
\hline \multirow[t]{2}{*}{ Total } & 1 old & 71.8 & 82.3 & 59.2 & 7.1 & 1.8 & 1.7 & 3.0 & 3.6 & 0.4 \\
\hline & 2 old & 84.5 & 85.7 & 72.4 & 4.8 & 1.9 & 3.6 & 1.3 & 2.5 & 0.0 \\
\hline SEM & & 2.179 & 1.642 & 0.332 & 0.895 & 0.508 & 0.692 & 0.528 & 0.590 & 0.198 \\
\hline \multicolumn{11}{|l|}{ Effects } \\
\hline Insemination method & & 0.032 & 0.682 & 0.074 & 0.095 & 0.622 & 0.444 & 0.786 & 0.652 & 0.329 \\
\hline Ganders age & & 0.001 & 0.331 & 0.002 & 0.213 & 0.902 & 0.138 & 0.102 & 0.417 & 0.329 \\
\hline Interaction & & 0.932 & 0.528 & 0.733 & 0.875 & 0.975 & 0.021 & 0.309 & 0.792 & 0.329 \\
\hline
\end{tabular}

Notes: SEM: Standard error of the mean; ${ }^{a, b}$ : The differences between the means shown in different letters in the same column are statistically significant; F: Fertility; H: Hatchability; IY: Incubation yield; EEM: Early embryonic mortalities; MEM: Middle embryonic mortalities; LEM: Late embryonic mortalities; PEM: Pipped embryonic mortalities; CE: Contaminated eggs; MDC: Morbid/dead chicks

\section{Sperm quality traits}

Sperm quality traits in natural mating and artificial insemination using 1- and 2-year-old ganders are provided in Tables 5 and 6. Semen volume, sperm concentration, sperm quality factor (SQF), and sperm motility were higher in the ganders used for artificial insemination compared to the ganders in the natural mating group $(p<0.05)$. In addition, in terms of all quality traits, 2 -year-old ganders had better quality sperm than the 1-year-old ganders $(p<0.05$; Table 5$)$. The interaction effect on sperm concentration was also found to be significant $(p<0.05)$.

Table 5 Sperm quality traits after natural mating and artificial insemination. 


\begin{tabular}{|c|c|c|c|c|c|}
\hline $\begin{array}{l}\text { Insemination } \\
\text { method }\end{array}$ & $\begin{array}{l}\text { Ganders } \\
\text { age }\end{array}$ & $\begin{array}{l}\text { Semen volume } \\
(\mathrm{mL})\end{array}$ & $\begin{array}{l}\text { Sperm concentration } \\
\left(\mathrm{n} \times 10^{6} \mathrm{~mL}^{-1}\right)\end{array}$ & $\begin{array}{l}\text { Sperm quality factor } \\
\text { (SQF) }\end{array}$ & $\begin{array}{l}\text { Sperm motility } \\
(\%)\end{array}$ \\
\hline \multirow[t]{3}{*}{ Natural mating } & 1 old & 0.18 & $220.47 d$ & $11.94 d$ & 46.77 \\
\hline & 2 old & 0.21 & $240.42 c$ & $16.25 c$ & 48.69 \\
\hline & Total & 0.19 & 229.92 & 13.98 & 47.68 \\
\hline \multirow{3}{*}{$\begin{array}{l}\text { Artificial } \\
\text { insemination }\end{array}$} & 1 old & 0.23 & $311.89 b$ & $23.28 \mathrm{~b}$ & 48.21 \\
\hline & 2 old & 0.26 & $370.19 a$ & $34.95 a$ & 50.13 \\
\hline & Total & 0.24 & 341.04 & 29.12 & 49.17 \\
\hline \multirow[t]{2}{*}{ Total } & 1 old & 0.21 & 269.86 & 18.07 & 47.55 \\
\hline & 2 old & 0.24 & 313.90 & 26.84 & 49.51 \\
\hline SEM & & 0.004 & 5.900 & 0.968 & 0.378 \\
\hline \multicolumn{6}{|l|}{ Effects } \\
\hline \multicolumn{2}{|c|}{ Insemination method } & 0.000 & 0.000 & 0.000 & 0.050 \\
\hline \multicolumn{2}{|l|}{ Ganders age } & 0.000 & 0.000 & 0.000 & 0.011 \\
\hline \multicolumn{2}{|l|}{ Interaction } & 0.415 & 0.012 & 0.010 & 0.998 \\
\hline
\end{tabular}

Notes: SEM: Standard error of the mean. ${ }^{a, b, c, d}$. The differences between the means shown in different letters in the column are statistically significant

The effect of the insemination method and age on total live and normal sperm in ganders was significant $(p<0.01)$. The ganders used for artificial insemination produced higher total live and normal semen in the 2-year-old ganders than the 1-yearold ganders compared to the naturally mating ganders. Macrocephalic sperm percentages were higher in natural mating ganders than those used for artificial insemination and were $27.51 \%$ and $26.53 \%$, respectively $(p<0.05)$. Bent-neck and midpiece sperm percentages were not affected by insemination type and age. However, immature sperm and other sperm deformities were significantly affected by the gander's age $(p<0.01)$. The immature sperm percentage was higher in 2-year-old ganders than 1-year-olds (6.53\% vs. 3.33\%). Other sperm deformities were found to be higher in 1-year-old ganders (6.62\% vs. $3.00 \%)$. Dead sperm percentages were also significantly higher in the natural mating ganders and 1-year-old ganders $(p<0.01)$.

Table 6 Sperm morphology traits after natural mating and artificial insemination 


\begin{tabular}{|c|c|c|c|c|c|c|c|c|c|}
\hline $\begin{array}{l}\text { Insemination } \\
\text { method }\end{array}$ & $\begin{array}{l}\text { Ganders } \\
\text { age }\end{array}$ & $\begin{array}{l}\text { Total } \\
\text { live } \\
\text { sperm } \\
(\%)\end{array}$ & $\begin{array}{l}\text { Normal } \\
\text { sperm } \\
(\%)\end{array}$ & $\begin{array}{l}\text { Macrocephalic } \\
\text { sperm } \\
(\%)\end{array}$ & $\begin{array}{l}\text { Bent- } \\
\text { neck } \\
\text { sperm } \\
(\%)\end{array}$ & $\begin{array}{l}\text { Mid-piece } \\
\text { deformed } \\
\text { sperm } \\
(\%)\end{array}$ & $\begin{array}{l}\text { Immature } \\
\text { sperm } \\
(\%)\end{array}$ & $\begin{array}{l}\text { Other } \\
\text { sperm } \\
\text { deformities } \\
(\%)\end{array}$ & $\begin{array}{l}\text { Dead } \\
\text { sperm } \\
(\%)\end{array}$ \\
\hline \multirow{3}{*}{$\begin{array}{l}\text { Natural } \\
\text { mating }\end{array}$} & 1 old & 89.77 & 29.55 & 27.62 & 15.97 & 7.00 & 3.32 & 6.55 & 10.22 \\
\hline & 2 old & 90.56 & 32.11 & 27.39 & 15.06 & 6.39 & 6.61 & 3.00 & 9.44 \\
\hline & Total & 90.14 & 30.76 & 27.51 & 15.54 & 6.71 & 4.88 & 4.87 & 9.85 \\
\hline \multirow{3}{*}{$\begin{array}{l}\text { Artificial } \\
\text { insemination }\end{array}$} & 1 old & 90.60 & 31.79 & 26.89 & 15.23 & 6.66 & 3.34 & 6.68 & 9.40 \\
\hline & 2 old & 91.32 & 33.87 & 26.17 & 15.32 & 6.49 & 6.47 & 3.00 & 8.68 \\
\hline & Total & 90.96 & 32.83 & 26.53 & 15.28 & 6.57 & 4.90 & 4.84 & 9.04 \\
\hline \multirow[t]{2}{*}{ Total } & 1 old & 90.22 & 30.76 & 27.23 & 15.57 & 6.82 & 3.33 & 6.62 & 9.78 \\
\hline & 2 old & 90.99 & 33.11 & 26.70 & 15.21 & 6.45 & 6.53 & 3.00 & 9.01 \\
\hline SEM & & 0.099 & 0.264 & 0.217 & 0.191 & 0.166 & 0.166 & 0.162 & 0.099 \\
\hline \multicolumn{10}{|l|}{ Effects } \\
\hline \multicolumn{2}{|c|}{ Insemination method } & 0.000 & 0.000 & 0.025 & 0.537 & 0.722 & 0.777 & 0.701 & 0.000 \\
\hline \multicolumn{2}{|l|}{ Ganders age } & 0.000 & 0.000 & 0.268 & 0.281 & 0.247 & 0.000 & 0.000 & 0.000 \\
\hline \multicolumn{2}{|l|}{ Interaction } & 0.876 & 0.620 & 0.573 & 0.194 & 0.513 & 0.726 & 0.701 & 0.876 \\
\hline
\end{tabular}

Notes: SEM: Standard error of the mean

\section{Discussion}

\section{Egg yield and broodiness}

Although geese were the first poultry to be domesticated, their reproductive behaviors depend on the season and geographical location (Shi et al. 2008; Kozák, 2019). In European countries, the reproduction period begins towards the end of January and ends in June (Gumulka andRozenboim, 2015). Data obtained from the present study were in line with those reported by Łukaszewicz et al. (2000), Gumulka and Rozenboim (2015), and Yu et al. (2016a). We determined that domestic geese have seasonal laying behaviors and a short egg-production period between January and June. Although the genetic structure and environmental factors influenced laying, this activity takes an average of 70-130 d (Bogenfürst, 2005; Gumułka and Rozenboim 2017)]. In the present study, the laying period was found to be $79 \mathrm{~d}$. The highest laying level was in February (19.4\%), followed by March (13.9\%), January (6.9\%), and April (3.5\%). Breeding studies on the reproductive traits of domestic geese have just begun, and the fact that the studies are conducted on populations taken from flocks in which natural breeding is used is a factor in low egg yield.

Broodiness is an important problem in commercial goose production (Qin et al. 2013) and is affected by factors such as genetic structure, environment, nutrition, and the level of hormones in the blood. Changing levels of reproductive endocrine hormones, including gonadotropin $(\mathrm{GnRH})$, prolactin (PRL), luteinizing hormone (LH), progesterone (P4), and estradiol (E2), have been considered to be the main factors causing brooding behavior (Yu et al. 2016b). In the present study, with the progression of the egg-production period, an increase in the level of brooding behavior was observed. The brooding behavior, which was never seen in January, increased to $69.4 \%$ in April. While egg production increased in January and February concurrent with low broodiness, egg yield decreased with increasing broodiness in March and April (Table 3). Negative relationships between brooding behavior and egg production have also been demonstrated in previous studies (Geng et al. 2013; Shimmura et al. 2010). Yao et al. (2019) report that geese with a high brooding rate have lower egg production than nongoose poultry species and that the rate of brooding can reach $60 \%$. 
Raveling (1978) has reported that synchronization of couple activities during the laying period can be an important determinant of reproduction success in geese. Hormones, such as progesterone and estradiol, regulate the development of follicles, laying, and sexual behavior in poultry (Liu et al. 2015), and varying levels of reproductive hormones are closely related to broodiness (Yu et al. 2016b). Therefore, our results support the conclusion that for males in the natural mating groups, keeping the ganders with the females can partially suppress broodiness in the females.

\section{Incubation traits}

Incubation traits in poultry may be affected by factors such as fertilization rate, storage time, egg weight, genetic structure, feeding, age, and disease (Elibol and Türkoğlu, 2014; Kırmızıbayrak et al. 2016). The findings of the present study were not compatible with those reported by Gumulka and Rozenboim (2018), who stated that the frequency of mating and sperm quality decreased due to low hormonal thyroid levels in the second half of the goose's laying period along with decreased fertility. In geese, the fertility rate and incubation efficiency values are generally lower than those in broiler chicken parent flocks and turkeys. With natural mating, the fertility rate in 2 -year-old geese has been reported at $82 \%$, and the incubation efficiency $75.3 \%$, somewhat lower than those determined in the present study (National Poultry Council-Chamber of Commerce, 2009). Nitsan et al. (1988) have reported that fertility from natural mating varied between $48 \%$ and $79 \%$. Another study stated that the fertility rate from natural mating in geese was lower than that of artificial insemination (Kowalczyk and Lukaszewicz, 2012) and that the fertility rate of artificial insemination was approximately 76\% (Kulaksız, 2016); however, in the present study, higher fertility rates were observed from natural mating (81.9-74.4\%). Gumulka and Rozenboim (2017) have reported that the frequency of courtship and mating in 2-year-old geese was higher than in 1-year-old geese, and 2-year-old geese showed a $150 \%$ increase in the frequency of sexual behavior over 1-year-old geese. In parallel, in the present study, we believe that sexual activity may be higher in the groups in which 2-year-old ganders were used and that this positively affected fertility.

\section{Sperm quality traits}

SQF is an important trait that affects fertility and shows that there are important differences among ganders (Gumulka and Rozenboim, 2013; Gumulka and Rozenboim, 2015; Lukaszewicz, 2002; Lukaszewicz and Kruszynski, 2003). Age, laying period, growing system, feeding, semen collection technique, and frequency, and some individual traits affect the amount and quality of the sperm (Lukaszewicz, 2010). In the present study, parallel changes in SQF were observed with the egg yield and sexual activity, peaking from the beginning of the laying period until February (Fig. 1). In line with the present study, tukaszewicz et al. (2000) and Łukaszewicz (2010) have reported that there may be fluctuations in sperm quality during the laying period, and the quality decreases as the period progresses. It has been reported that testosterone regulates sperm production and activation of sexual behaviors in ganders (Hirschenhauser, 1999), and decreased levels of testosterone can be effective in both males and females (Hirschenhauser, 1997). SQF, which includes the three most important sperm traits, evaluates semen volume, sperm concentration, and percentage of live normal sperm together and is used to estimate the fertilization potential of the sperm (Lukaszewicz and Kruszynski, 2003). The semen volume varied between $0.18-0.26 \mathrm{~mL}$ during the laying period, which was similar to those reported by Gumulka and Rozenboim (2015), who worked with the Zatorska goose genotype, and partially lower than the 0.18-0.90 mL reported by Liu et al. (2008) in Yangzhou geese. Sperm concentration, SQF, and motility levels show great variations depending on genotype, age, and laying period (Gumulka and Rozenboim, 2015; Jerysz and Lukaszewicz, 2013; Liu et al. 2008; Lukaszewicz, 2010). The findings of the present study were not compatible with those reported by Łukaszewicz (2010), who reported that SQF increased as the laying period progressed. In the present study, SQF, which increased from January to March, decreased gradually in April and May. Although SQF values varied during the laying period, they were similar to the SQF values reported by Gumulka and Rozenboim (2015), which varied between $6.4 \%$ and $37.3 \%$, lower than those reported by Łukaszewicz (2010). In the present study, the SQF increased from the beginning of the laying period to end of the February and then gradually decreased in the following months. This pattern may have been caused by hormonal changes resulting from genetic structures and geographical conditions.

Because there are many uncontrollable factors that affect natural mating conditions, the reproductive performance and sustainability of sperm quality become difficult, and problems can occur during fertility and embryonic development. Sperm quality decreases at the beginning and in the last 6 weeks of the laying period, and sperm morphology deteriorates, affecting

Page $10 / 15$ 
fertilization success (Lukaszewicz, 2010). The higher sperm quality in 2-year-old ganders may be explained by their more fully developed organs for sperm production and the sexual experience they have gained. The fact that geese are a monogamic poultry species causes sexual behavior problems that may result from preferential mate selection, which may not affect sperm yield and quality (Lukaszewicz, 2010). In addition, a naturally mating gander mates $0.74-1.79$ times/d during the laying period and sometimes can perform less than one successful mating per day on average (Gumułka and Rozenboim, 2013). In the present study, higher quality and higher amounts of sustainable sperm could be obtained artificially from the ganders because, unlike natural mating, there are no problems arising from male-male and male-female antagonistic relationships (social hierarchy), and unnecessary mating is prevented (Gumułka and Rozenboim, 2017).

Only morphologically normal sperm can reach the area where the storage tubes are located from the vagina, so ganders with a high rate of morphologically normal sperm must be used to ensure fertilization success (Bakst et al. 1994; Liu et al. 2008). The viability and life strength of sperm are especially important factors for reproductive success in local genotypes (Froman and Feltmann, 1998; Froman and Feltmann, 2000; Froman et al. 2003). In the present study, live sperm and normal sperm levels were found to be satisfactory and were between $89.83 \%$ and $91.48 \%$ and $27.78 \%$ and $34.95 \%$, respectively, and were similar to those reported by Gumulka and Rozenboim (2015) and Lukaszewicz, (2010); whereas these levels were higher than those reported by Svoradova et al. (2019). Our results were similar to those reported by Łukaszewicz (2010), who observed that live and normal sperm levels are low at the beginning of the laying period and tend to gradually increase. In the present study, the relatively lower live and normal sperm levels increased gradually from January but decreased after March and April. In addition, the results of the present study were compatible with those reported by Łukaszewicz $(2002 ; 2010)$, who observed that the semen of 2-year-old ganders has higher live sperm counts than that of 1-year-old ganders, but normal sperm levels did not change significantly with gander age. Compared to those reported by Gumulka and Rozenboim (2015), who observed that deformed sperm levels (e.g., macrocephalus, large neck, and abnormal midpiece) were within the ranges of 14.3-20.0\%, 9.1$12.1 \%$, and $3.5-5.3 \%$, respectively. In our study, we observed sperm with poorer quality morphology; however, our findings, which were similar to those of Łukaszewicz (2010) in terms of sperm levels with macrocephalus and an abnormal midpiece, were higher than those reported by Łukaszewicz (2002). In addition, the findings were partially similar to those of Łukaszewicz (2010), who observed that the level of macrocephalic sperm with a large neck and abnormal midpiece did not change significantly between 1- and 2-year-old ganders. In the present study, similar to the results of Łukaszewicz (2010), 2-year-old ganders were observed to produce more immature sperm but fewer other deformations compared to 1-year-old ganders. The dead sperm levels also showed an inverted bell curve over the laying period. The level of dead sperm, which was $10.17 \%$ at the beginning of the laying period, dropped to $8.52 \%$ in March and increased to $10.00 \%$ in May. The dead sperm levels determined in the present study were compatible with the results reported by Jerysz and Łukaszewicz (2013) of between $6.0 \%$ and $9.0 \%$.

\section{Conclusion}

This study is the first study to compare the reproduction, hatching, and sperm quality traits of domestic Turkish geese mated naturally and inseminated artificially. The results showed that the egg production level was low, and the brooding behavior was high in domestic geese. It was determined that the incubation results of the natural mating and artificial insemination groups were similar, and the resulting differences were mostly due to age factors. Two-year-old male geese were used for improved fertility and hatchability compared compared to the 1-year-olds. In terms of sperm quality traits, it was determined that artificial insemination with two-year-old males gave good results and had a good fertility capacity in terms of SQF value. The morphological traits of semen change depending on the age and the laying period rather than the insemination type.

As a result, domestic geese need improvement in terms of egg yield and brooding traits, and the use of two-year-old ganders in artificial insemination will contribute positively to commercial production and the breeding process.

\section{Declarations}

\section{Acknowledgments}

This study was supported by Yozgat Bozok University (Project no: 6602b-ZF/18-148).

Page $11 / 15$ 


\section{Funding}

This study was supported by Yozgat Bozok University (Project no: 6602b-ZF/18-148).

\section{Conflicts of interest/Competing interests}

The authors have no relevant financial or non-financial interests to disclose.

The authors have no conflicts of interest to declare that are relevant to the content of this article.

All authors certify that they have no affiliations with or involvement in any organization or entity with any financial interest or non-financial interest in the subject matter or materials discussed in this manuscript.

The authors have no financial or proprietary interests in any material discussed in this article.

\section{Availability of data and material}

Data and materials are available.

\section{Code availability}

The software application can be accessed.

\section{Authors' contributions}

All authors were equally supported.

\section{Ethics approval (include appropriate approvals or waivers)}

The experimental protocol was approved by the Ethical Committee on Animal Experimentation of the University of Niğde Ömer Halisdemir (6837521-050.99-E.980, 18/08/2017).

All procedures in the study are carried out in accordance with the "Regulation on the Welfare and Protection of Animals Used for Experimental and Other Scientific Purposes" numbered 28141 published on 13 December 2011.

\section{References}

Arslan C, Saatçi M (2003) Egg yield and hatchability characteristics of native geese in the Kars region. Turk J Vet Anim Sci 27:1361-1365

Bakst MR, Wishart G, Brillard JP (1994) Oviductal spermatozoa selection, transport, and storage in poultry. Poult Sci Rev 5:117143

Bogenfürst F (2005) Effect of nutrition on the reproductive parameters of geese. Proceedings of the 15th European Symposium on Poultry Nutrition, Balatonfüred, Hungary; World's Poultry Science Association (WPSA) 64-73. Accessed 18 October 2018

Boz MA, Sarıca M, Yamak US (2014) Goose production in province Yozgat. J Poult Res 11:16-20

Demir P, Kırmızıbayrak T, Yazıcı K (2013) Socio-economic importance of goose breeding. Ankara Univ Vet Fak Derg 60:129-134

Elibol O, Türkoğlu M (2014) Embriyo Gelişimi ve Kuluçka. In: Türkoğlu M, Sarıca M, editors: Tavukçuluk Bilimi (Yetiştirme, Besleme, Hastalıklar). 4th ed. Ankara: Bey Ofset Matbaacılık pp 166-206 (in Turkish)

Froman DP, Feltmann AJ (1998) Sperm mobility: A quantitative trait of the domestic fowl (Gallus domesticus). Biol Reprod 58:379-384. https://doi.org/10.1095/biolreprod58.2.379

Page $12 / 15$ 
Froman DP, Feltmann AJ (2000) Sperm mobility: Phenotype in roosters (Gallus domesticus) determined by concentration of motile sperm and straight line velocity. Biol Reprod, 62:303-309. https://doi.org/10.1095/biolreprod62.2.303

Froman DP, Bowling ER, Wilson JL (2003) perm mobility phenotype not determined by sperm quality index. Poult Sci 2:496502. https://doi.org/10.1093/ps/82.3.496

Geng AL, Shi XL, Zhang Y, Ma YJ (2013) Study of broody and egg-laying behavior and characteristics of Beijing You Chicken. Chin Poult 9:6-10

Grunder AA, Pawluczuk B (1991) Comprasion of produres for collecting semen from ganders and insemiating geese. Poult Sci 70:1970-1980. https://doi.org/10.3382/ps.0701975

Gumulka M, Rozenboim I (2013) Mating activity of domestic geese ganders (Anser anser f. domesticus) during breeding period in relation to age: testosterone and thyroid hormones. Anim Reprod Sci 142:183-190.

https://doi.org/10.1016/j.anireprosci.2013.09.021

Gumulka M, Rozenboim I (2015) Breeding period-associated changes in semen quality, concentrations of LH, PRL, gonadal steroid and thyroid hormones in domestic goose ganders (Anser anser f. domesticus). Animal Reprod Sci 154:166-175. https://doi.org/10.1016/j.anireprosci.2014.11.021

Gumułka M, Rozenboim I (2017) Effect of the age of ganders on reproductive behavior and fertility in a competitive mating structure. Ann Anim Sci 17:733-746. https://doi.org/10.1515/aoas-2016-0071. https://doi.org/10.1515/aoas-2016-0071

Hirschenhauser K, Dittami J, Mostl E, Wallner B, Kotrschal K (1997) Testosterone and behaviour during different phases of reproduction in Greylag Geese (Anser anser). Adv Ethol 32: 61

Hirschenhauser K, Mostl E, Kotrschal K (1999) Within pair testosterone covariation and reproductive output in Greylag Geese Anser anser. Ibis 141:577-586. https://doi.org/10.1111/j.1474-919X.1999.tb07365.x

Jerysz A, Lukaszewicz E (2013) Effect of dietary selenium and vitamin E on ganders' response to semen collection and ejaculate characteristics. Biol Trace Elem Res 153:196-204. https://doi.org/10.1007/s12011-013-9652-5

Kırmızıbayrak T, Boğa Kuru B, Yazıcı K (2016) Yield and traits of geese eggs and hatchability traits. Turkiye Klinikleri J Reprod Artif Insemin 2:42-47

Kowalczyk A, Lukaszewicz E (2012) The possibility of obtaining intergeneric hybrids via White Kołuda (Anser anser L.) goose insemination with fresh and frozen-thawed Canada goose (Branta canadensis L) gander semen. Theriogenology 77:507-513. https://doi.org/10.1016/j.theriogenology.2011.08.025

Kozák J (2019) Variations of geese under domestication. World's Poult Sci J 75:247-260.

https://doi.org/10.1017/S0043933919000023

Kulaksız R (2016) Storage of goose semen. Turkiye Klinikleri J Reprod Artif Insemin 2:15-19

Labatut MC (2002) Goose production in Chile and South America. In: Buckland R, Guy G. editors, Goose Production, FAO Animal Production and Health Paper, No: 154, Roma, Italy. Part II. Invited papers.

Liu SJ, Zhneg JX, Yang N (2008) Semen quality factor as an indicator of fertilizing ability for geese. Poult Sci 87:155-159. https://doi.org/10.3382/ps.2007-00300

Liu H, Zhang W, Li Q, Liu J, Zhang T, Zhou T, Li L, Wang J, Xu H, He H (2015) The comprehensive mechanisms underlying nonhierarchical follicular development in geese (Anser cygnoides). Anim Reprod Sci 159:131-140.

https://doi.org/10.1016/j.anireprosci.2015.06.007

Page $13 / 15$ 
Lukaszewicz E, Furuta H, Xi YM, Fujihara N (2000) Comparative study on semen quality of one and two-year old ganders during the entire reproductive season. Asian J Androl 2:139-142

Lukaszewicz E (2002) An effective method for freezing White Italian gander semen. Theriogenology 58:19-27.

https://doi.org/10.1016/S0093-691X(01)00690-2

Lukaszewicz E, Kruszynski W (2003) Evaluation of fresh and frozen-thawed semen of individual ganders by assessment of spermatozoa motility and morphology. Theriogenology 59:1627-1640. https://doi.org/10.1016/S0093-691X(02)01209-8

Lukaszewicz E (2010) Artificial insemination in geese. World's Poult Sci J 66:647-657.

https://doi.org/10.1017/S0043933910000632

National Poultry Council-Chamber of Commerce (2009) Results of the evaluation poultry performances in the year 2008, Warsaw

Nitsan Z, Nir I, Dvorin A (1988) Reproductive performance of laying geese kept in flocks or in individual pens. Proceedings of International Symposium on Waterfowl Production, The Satelite Conference for the XVIII World Poultry Congress; Beijing, China. pp 278-280

Qin Q, Sun A, Guo R, Lei M, Ying S, Shi Z (2013) The characteristics of oviposition and hormonal and gene regulationof ovarian follicle development in magang geese. Reprod Biol Endocrinol 11:65-75. https://doi.org/10.1186/1477-7827-11-65

Raveling DG (1978) The timing of egg laying by northern geese. Auk 95:294-303

Shi ZD, Tian YB, Wu W, Wang ZY (2008) Controlling reproductive seasonality in the geese: a review. World's Poult Sci J 64:343355. https://doi.org/10.1017/S0043933908000081

Shimmura T, Kamimura E, Azuma T, Kansaku N, Uetake K, Tanaka T (2010) Effect of broody hens on behaviour of chicks. Appl Anim Behav Sci 126:125-133. https://doi.org/10.1016/j.applanim.2010.06.011

Svoradová A, Baláži A, Vašíček J, Hrnčár C, Chrenek P (2019) Quality evaluation of fresh gander semen of Slovak White Goose by CASA and flow cytometry. Slovak J Anim Sci 52:90-94. Record Number: 20193332579

Tilki M, İnal Ş (2004) Yield traits of geese of different origins reared in Turkey I. Hatching traits. Turk J Vet Anim Sci 28:149-155

Yao Y, Yang YZ, Gu TT, Cao ZF, Zhao WM, Qin HR, Xu Q, Chen GH (2019) Comparison of the broody behavior characteristics of different breeds of geese. Poult Sci 98:5226-5233. https://doi.org/10.3382/ps/pez366

Yu J, Lou Y, Zhao A (2016a) Transcriptome analysis of folli-cles reveals the importance of autophagy and hormones in regulating broodiness of Zhedong white goose. Sci Rep 6:36877. https://doi.org/10.1038/srep36877

Yu J, Lou Y, He K, Yang S, Yu W, Han L (2016b) Goose broodiness is involved in granulosa cell autophagy and homeostatic imbalance of follicular hormones. Poult Sci 95:1156-1164. https://doi.org/10.3382/ps/pew006

\section{Figures}




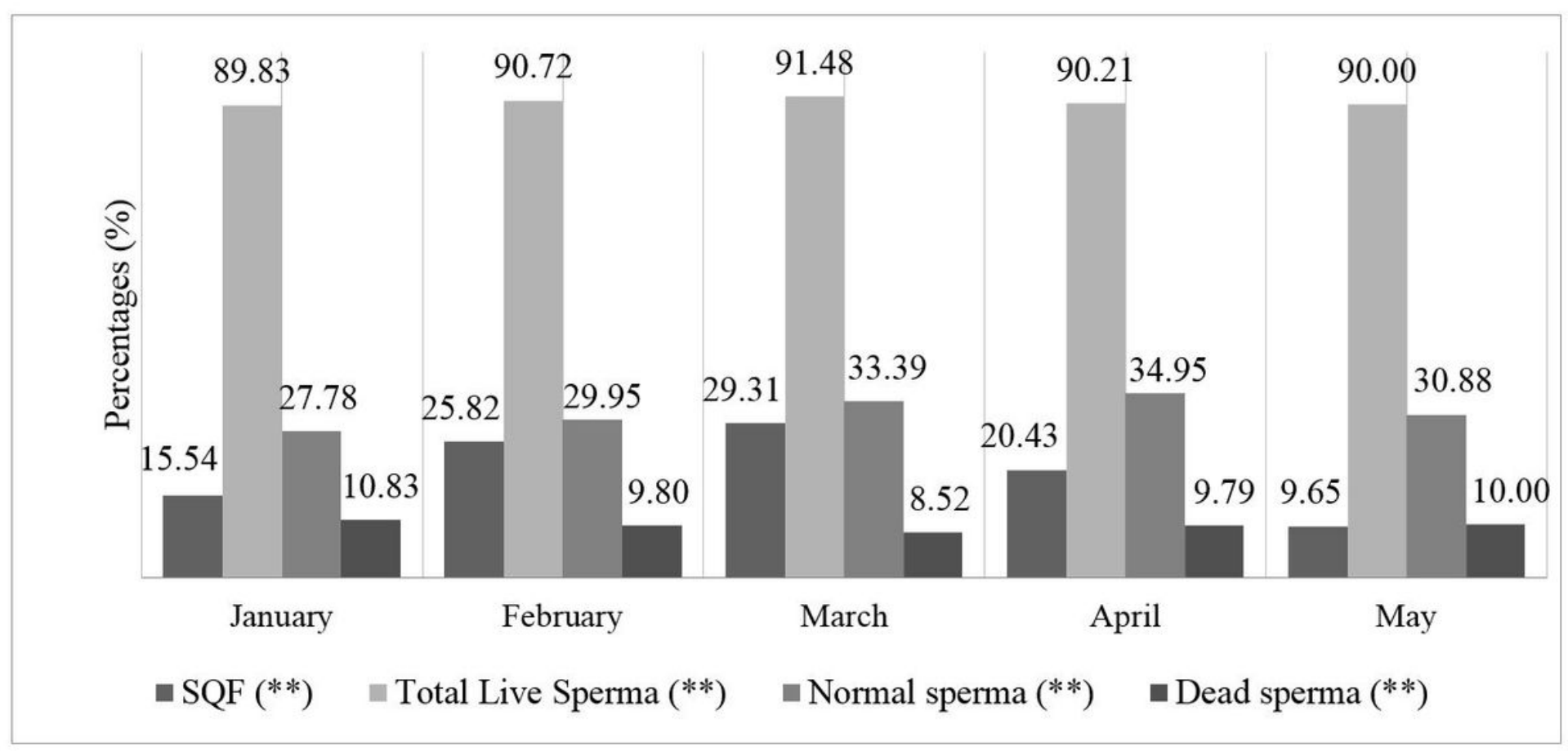

Figure 1

Changes based on the semen collection period during the study. Notes: SQF: Sperm quality factor; $\star *: P<0.01$ 